\title{
CARRIAGE OF GOODS BY SEA AS A SPECIAL FORM OF LOCATIO-CONDUCTIO OPERIS FACIENDI IN ROMAN LAW
} UDC 347.79(37)

\section{Marija Ignjatović}

\author{
Faculty of Law, University of Niš, Serbia
}

\begin{abstract}
Carriage of goods by sea, as a special form of locatio-conductio operis faciendi contract, was particularly interesting in Roman law in the social circumstances related to the period after the Punic wars. It was the period of expasion of the Roman state, characterized by the development of maritime trade, which called for rapid and effective conclusion of contracts in legal affairs. Considering the growth of maritime trade, there was a need to introduce relevant legal instruments which would help meet the increasingly demanding trade of goods. This led to the creation of contract of carriage of goods by sea which was, in Roman law, a specific form of locatio-conductio, specifically locatioconductio operis faciendi. In order to conclude and ensure the validity of this contract, in addition to the agreement between the contracting parties, it was also necessary to fulfill the conditions regarding the subject matter of the contract. The subject matter of this contract was not work itself or workforce, but the final result of work (opus), i.e. to transport goods from one place to another, and a fee (merces) paid for such services.
\end{abstract}

Key words: maritime trade, carriage of goods by sea, locatio-conductio operis faciendi, opus, merces.

\section{INTRODUCTION}

Carriage of goods by sea, as a special form of locatio-conductio contract, is first mentioned in the period after the Punic wars, when the Roman state geographically expanded, alongside with the development of maritime trade. By occupying the surrounding nations, the Romans came in contact with the Oriental culture, which was at a much higher level than the Roman culture. During this period, Rome became a powerful and geographically large state, due to frequent wars and increasingly developing trade (Casson, 1960: 225-233). In this period, Rome was no longer a small monolithic community, spreading out over seven hills (septimontium); in fact, it covered the entire Apennine Peninsula (with quite a heterogeneous

Received October $25^{\text {th }}, 2018 /$ Accepted November $13^{\text {th }}, 2018$

Corresponding author: Prof. Marija Ignjatović, LL.D., Faculty of Law, University of Niš, Trg kralja Aleksandra 11, 18000 Niš, Republic of Serbia

E-mail: marija@prafak.ni.ac.rs 
population) (Ignjatović, 2002: 328) and, after defeating the Carthaginians, the whole Mediterranean area (Ignjatović, 2017: 186). In this period, the first provinces were created (Sicily and Sardinia).

The Mediterranean connected the world more than ever. Travelling by sea developed, primarily, because of commercial needs. "Until II century B.C., a large part of transportation was done by land, which was very expensive and connected with many disadvantages; more and more developed trade connections with newly conquered areas, the import of sustainable food and luxury products from distant areas, as well as the transport of passengers and slaves, resulted in the rapid development of maritime transport" (Šarac, 2008: 115). Roman ships travelled across the Mediterranean Sea, the Black Sea and Red Sea, as far as India in the east, along the coast of modern Morocco in the west, and all the way to Britain in the north-west. They mostly travelled in the period from spring to autumn, usually by day. The port of Rome was Ostia, at the mouth of the river Tiber, while Brundisium (modern Brindisi) was a port from which ships used to set off to Greece and further in the east. The famous ports in Greece were Greek towns Piraeus (in Attica) and Ephesus (in Asia Minor), as well as the islands Delos, Rhodes and Cyprus. The largest Mediterranean port was Alexandria in Egypt, where large cargo ships loaded with wheat started their journey to Rome.

The most significant trade was the one between Rome and provinces. They had to import certain products which were scarce in Rome, and a surplus of some products from Rome and the surrounding area was sold in provinces (Maškin, 1997: 149). Larger towns by the sea developed into big and well-known trade centres, some of which specialized in a particular type of trade. ${ }^{1}$ The period after the Punic wars, the suppression of pirates and the use of military roads exclusively for commercial purposes were especially favourable for the general development of trade (Stojčević, 1947: 47). The majority of items were produced for the local population and the local market demand, but there were particular regions of the Empire which specialized in making certain products, for the purchase of which merchants sometimes travelled long distances, occasionally even crossing the borders of the Empire.

Apart from the geographical expansion, the Roman conquests of the neighbouring nations led to contacts with different cultures and different properties. Those circumstances generated a need to create new legal rules which would suit the new situation (Nikčević-Grdinić, 2007: 263), with the purpose of regulating contractual relations and the development of maritime trade (Rouge, 1966:389) with the most distant parts of the Empire.

Although the Romans were famous for their legal ingenuity, legal logic, interpretation of the law and formation and creation of legal rules in accordance with the needs of legal practice (Ignjatović, 2016: 325-338), it is unlikely that they were those who created the laws of maritime trade. It is a fact that they were not known as a maritime nation in history; a long time before them, this trait was attributed to the Hellenic nation whose maritime law was developed in IX century BC (lex Rhodia de iactu) (Ignjatović, 2017: 186). Thanks to the reception of the maritime law from the island of Rhodes, the Romans were ready for the development of maritime trade. The presence of these Hellenic foundations in the development of maritime lawoffered an opportunity to the Romans to further develop this field of law, not only through the reception of legal provisions on the

${ }^{1}$ In Pozzuoli, in the Bay of Naples, a huge number of products made of metal and intended for export were produced. On the other hand, after conquering Sicily, the whole province was transformed into a large wheat field which, along with Egypt, was supposed to provide food for millions of people living in Rome and Italy. Ore was imported from Spain, and luxurious items were imported from eastern countries. 
common average, about bearing and sharing the risk caused by accidents which could happen during the transport of goods by sea but also through the introduction of new institutes, primarily in the form of maritime loan (feonus nauticum), as well as through the creation of new procedural instruments aimed at protecting the interests of users of services of maritime ventures (passengers).

Based on the analysis of relevant legal sources, this paper discusses some issues related to the transport of goods by sea, based on the aforementioned explanations. Thus, the subject matter of analysis of this paper will be the contract of carriage of goods by sea.

\section{THE AgREEMENT ON THE TRANSPORTATION OF GOODS By SEA AS A SPECIAL TYPE OF AGREEMENT LOCATIO-CONDUCTIO}

As pointed out in the introductory part of the paper, the idea of a special type of agreement locatio-conductio, the agreement on the transportation of goods by sea, is first mentioned in the period of the Roman Republic, when the Roman state started to expand geographically, and especially when maritime trade started to develop. When they occupied the neighboring nations, the Romans came into contact with the oriental culture, which was at a much higher level than the Roman culture. That was a period of "obsession with anything that was Greek" (Stojčević, 1947: 51). However, the base for overall changes in the period of the Republic was not only learning about Greek culture but also the prominent development of trade, which caused a new division in the social structure. A farmer was replaced by a trader (Stojčević, 1947: 51).

The change in the social structure and the contact with Greece had an influence on social awareness and, accordingly, on the change in the perception of the essence of legal relations as well as on the acceptance of new legal rules under pressure of commercial demands. The Romans increasingly abandoned the formalism of the old law, which had been perceived as the basis for legal action, and they placed emphasis on consensus, the consent of will of the contracting partiess, as well as on their preferences when agreeing about a legal transaction (Stojčević, 1947:52).

After defeating the Greek islands, especially Rhodes, the Romans came into contact with the existing rules used to regulate maritime trade. ${ }^{2}$ Due to that, the agreement on the transport of goods by sea was defined in accordance with the adopted provisions of the maritime law of the island of Rhodes (Bolanča, Amižić, Pezelj, 2017: 1-11), which was named Lex Rhodia de iactu (Simonović, 2009:905-915) by the Romans. Therefore, the agreement on carriage of goods by sea, which was given the same name "Lex Rhodia de iactu ("The Rhodian law of jettison"), represents a typical example of what we could call a successful legal transplant; moreover, it was not transplanted through some imposed solution but through a rule which was willingly well implemented by the recipient system (the Roman law) from the donor system (the maritime law of Rhodes) (Đorđević, 2014: 262).

\footnotetext{
${ }^{2}$ Rhodes was a strong, independent, maritime and trade island, south of modern Greece. In the period between 1000-600 BC, people from Rhodes developed a strong trade fleet, which was the first one on the Mediterranean. It had a further influence on the development of trade fleets along the western coast of Italy, France and Spain. At the same time, the inhabitants of Rhodes developed legal rules which they used to solve numerous problems related to the transportation of goods by sea, including, most probably, the enforcement of the first law in the field of the maritime law, which is called Lex Rhodia de iactu in modern science. For more, see: Momsen \& Kruger, Lex Rhodia de iactu, Digesta XIV, 2; http://www.duhaime.org/lawMuseum/Law article - 383/LexRhodia-The-Ancient-Ancestor-of-Maritime-Law-800-BC.aspx
} 


\section{CARRIAGE OF GOODS BY SEA AS A SPECIAL FORM OF LOCATIO-CONDUCTIO OPERIS FACIENDI IN ROMAN LAW (GENERAL CHARACTERISTICS)}

In Roman law, the agreement on transportation of goods by sea was a specific form of the agreement locatio-conductio, more precisely locatio-conductio operis faciendi; thus, all rules which were applied to this agreement were also applied to its specific form (subtype), to the agreement on the transportation of goods by sea.

The agreement on the transportation of goods by sea, as a specific form of locatioconductio operis faciendi, represented a consensual bona fides agreement, binding on both contracting parties, defined during the period of the Roman Republic and protected by action conducti and action locati. Under this contract, one party (conductor) made a commitment to perform a certain activity within a specified time, and the other party (locator) was obliged to pay a particular amount of money in return (Đorđević, 2014:251).

\subsection{Subject of the contract}

The subject of this agreement was not the commissioned work or workforce but the final result of work (opus), i.e. transportation of goods from one place to another, as well as a payment (merces) which was made for the service. In order for this agreement to be concluded and made valid, beside the consent of wills of the contracting parties, it was necessary to fulfil conditions regarding the delivery of goods for the commissioned work. All loaded goods had to be written down in the logbook and a detailed inventory was made "in scriptis". A document, which included a complete inventory of the goods, was not available to traders. That primitive form of a bill of lading had to include the name of the property owner, a list of goods, labels, weight and the amount.

\subsection{Contracting parties}

The agreement was made between the owner of property and the captain of a ship, who was, as a rule in the ancient times, the owner of the ship (dominus navis) (Pezelj, 2017: 311335 ); therefore, he was in charge of the ship and he also collected payments for provided services. This was quite understandable, especially considering maritime situation of that era. Insufficiently developed maritime trade necessarily imposed the need for the ship owner to command the ship and to be largely responsible for its maintenance (Šarac, 2008:85).

However, the validity of an agreement could depend on a third party, which happened somewhat later, after the Punic wars, when new opportunities for the financial and economic growth of the Roman state emerged. With the increase in material wealth and the transition to a market economy, it was necessary to divide the work between the owner of the ship (which had its post in the domestic port) and the ship commander who sailed for the owner (Šarac, 2008:85). Thus, in addition to executor navis, a third person could command a ship if the ship owner authorized him as his representative (magister navis, usually a slave or a person alieni iuris), who deputized the ship owner and, technically, managed the ship (Ignjatović, 2017: 190). Exercitor navis was a ship owner, or a shipper, i.e. the party which organized the navigation venture and gained all advantages or sustained all damage resulting from giving a ship, while magister navis was the captain of a ship (Šarac, 2008:115).

However, it was not easy to arrange the division of labor between the ship owner and the ship captain because the basic principles of Roman law made it difficult, or even 
impossible, to enter into a legal contract with subordinate persons or in cases when persona extranea was the ship captain, due to their inadequate payment capacity. On the other hand, it was necessary to protect the interests of third parties that concluded certain legal affairs and thus increase the level of mutual trust and security. This was accomplished in the II century B.C. by the intervention of the praetor, who introduced a special means of legal protection: actio exercitoria. Through this institute, the responsibility of the ship owner was established, i.e. the responsibility of the person who appointed a slave, a son or persona extranea to act as the captain of the ship (magister navis) for obligations arising from the affairs of those persons who were responsible for the transport of goods by sea and ship management (Šarac, 2008:86).

\subsection{Rights and obligations}

Considering the double-binding character of this contract, both the locator and the conductor were bound by rights and obligations arising from the contract. The obligation of embarkation of goods was directly related to the locator (the one who ordered the service) and it was a necessary presupposition for this type of locatio-conductio operis faciendi. Besides, due to the nature of this agreement, the term "goods" referred to all movables, both consumables and non-consumables. In case of transporting movable and non-consumable goods, as a rule, the conductor had custody of the property. However, in case of movable and consumable goods (such as wine or wheat), the conductor would become the owner of the property at the moment of taking it, thus assuming an obligation to give back the same amount of the same type of property after finishing transportation. Another obligation of the locator was to pay the price for the transportation of goods. As a rule, the price was expressed in money but it was possible to make other arangements (Stanojević, 2009:249). Finally, the locator was obliged to organize not only embarking but also disembarking of goods, after the ship safely reached the port. For the protection of his rights, the locator could rely on action locati. In case of theft or damage of goods during the transportation by sea, he could use action furti et damni adversus nautas and the general actio in factum (Pezelj, 2017:318).

Transported goods usually belonged to a number of different owners, and only in rare cases did they belong to a single owner. As the transported goods were owned by a number of creditors (locators who ordered the service), the owners sustained unequal damage in case of jettison (accidents, pirate attacks, storms, etc.). Thus, a question arose whether it was in accordance with the main idea of law that, in circumstances when the goods of one owner were sacrificed for the common benefit of other owners, the victim should be the only one responsible for the loss. The solution for this situation could be found in Lex Rhodia de iactu, which provided that in case of common average all creditors (locators), as well as the ship owner (conductor), should share any losses in solidum in proportion to the value of the saved goods.

Paul. D. 14, 2, 1. LEGE RHODIA CAVETUR, UT SI LEVANDAE NAVIS GRATIA IACTUS MERCIUM FACTUS EST, OMNIUM CONTRIBUTIONE SARCIATUR QUOD PRO OMNIBUS DATUM EST (Boras, Margetić, 1980:166).

The obligation of a conductor was to complete the commissioned work (transportation of goods by sea). Therefore, the subject of his obligation (opus) was a result of his work provided transportation of goods by sea. This was necessarily related to the price, which he 
was permitted to accept only after completing the entrusted task. Besides, his liability was to provide safe transportation of goods, and to handle the entrusted goods with utmost care, like bonus pater familias. That is why his liability was not omnis culpa but, in certain cases, he was also responsible for the competence of his crew members and his assistants, and in some other cases, for custodia as well. This type of responsibility additionally aggravated the position of conductors, since their responsibility had already been increased, and in the age of the Republic it was marked as objective responsibility (culpa in custodiendo). The introduction of this aspect of responsibility was necessary because it was the foundation for the relation of trust between the provider and the user of a service. On the other hand, the absence of this aspect of responsibility led to the general state of unsafety; thus, ship owners had a bed reputation for a while because it was believed that they often organized cooperation with thieves, with the aim of gaining unlawful property gain (Bujuklić, 2013:432).

\subsection{Procedural means of protection}

On the other hand, the rapid development of trade necessitated quick and efficient conclusion of contracts in legal affairs. Yet, there were situations where the ship owner did not have time to inquire in detail about the qualities and personal characteristics of the ship captain, due to the difficult weather and local conditions (Šarac, Miletić, 2017: 423). For this reason, in accordance with the principle of equity, the praetor introduced a lawsuit against the conductor in cases when the ship owner or ship captain acted on his behalf. This rule on actio exercitoria and actio institoria is written in Gaius Institutiones (Book 4, paragraph 71).

Gai, IV, 71: EADEM RATIONE CONPARAVIT DUAS ALIAS ACTIONES, EXERCITORIAM ET INSISTORIAM. TUNC AUTEM EXERCITORIA LOCUM HABET, CUM PATER DOMINUSVE FILIUM SERVUMVE MAGISTRUM NAVI PRAEPOSUERIT, ET QUID CUM EO EIUS REI GRATIA CUI PRAEPOSITUS FUERIT GESTUM ERIT. CUM ENIM EA QUOQUE RES EX VOLUNTATE PATRIS DOMINIVE CONTRAHI VIDEATUR, AEQUISSIMUM ESSE VISUM EST IN SOLIDUM ACTIONEM IN EUM DARI. QUIN ETIAM, LICET EXTRANEUM QUISQUE MAGISTRUM NAVI PRAEPOSUERIT SIVE LIBERUM, TAMEN EA PRAETORIA ACTIO IN EUM REDDITUR. IDEO AUTEM EXERCITORIA ACTIO APPELLATUR, QUIA EXERCITOR VOCATUR IS, AD QUEM COTTIDIANUS NAVIS QUAESTUS PERVENIT.

Therefore, a locator had the right to file a lawsuit against the ship owner in all those situations where the ship captain caused damage to the locator in the performance of his duties. As the basis of responsibility was the will of the ship owner (voluntas), the ship owner was fully accountable (in solidum) (Šarac et al., 2017: 424). This was also the case when the ship owner authorized a slave or a third person, who was not his alieni iuris, to be the captain (Šarac et al., 2017:424). If the captain was a person alieni iuris, then the ship owner was fully accountable for the work he entrusted to this person, as well as for the work he subsequently approved. Otherwise, he was accountable only for the value of the property of a person alien iuris (in peculium).

According to Ulpian, the responsibility of the ship owner was in solidum because it was based on sua voluntate. As such, it was permanent. This further meant that his responsibility could be inherited, and the claim could have been raised by third parties 
after his death, even against his successors. The responsibility of the ship owner did not cease even in the event of a death of the ship captain or the change in his status due to the captitis deminutio (Šarac et al., 2017:426).

D.14.1.4.3 (Ulp. 29 ad ed): SI SERVUS SIT, QUI NAVEM EXERCUIT VOLUNTATE DOMINI, ET ALIENATUS FUERIT, NIHILO MINUS IS QUI EUM ALIENAVIT TENEBITUR. PROINDE ET SI DECESSERIT SERVUS, TENEBITUR: NAM ET MAGISTRO DEFUNCTO TENEBITUR.

Starting from the interests of third parties and the need for their protection, the praetor therefore found that the ship owner could always be suid under the actio exercitoria. However, if the ship captain caused damage to the locator, by performing a job against the will of the ship owner, in that case he was personally accountable to the locator based on the locatio-conductio if he received some compensation for that job, or if it was not the case, then on the basis of the mandatum contract. It was considered that the ship captain was obliged to conclude only those jobs for which he received the order from the ship owner (Šarac et al., 2017: 427). Also, the ship owner could designate more persons for the captain of the ship, and in that case, he was responsible for all the obligations that they would have assumed within the activity for which they received an order from the ship owner.

\section{CONCLUSION}

In Roman law, carriage of goods by sea, as a special form of locatio-conductio operis faciendi contract, was becoming particularly interesting in the social circumstances after the Punic wars. By occupying the surrounding nations, the Romans came in contact with the Oriental culture, which was at a much higher level than the Roman culture. The Mediterranean connected the world more than ever. Travelling by sea developed, primarily, for commercial needs. Until II century B.C, a large part of transportation was done by land, which was very expensive and connected with many disadvantages, such as: interception by robbers, weather conditions, etc.). The development of trade connections with newly conquered areas, the import of sustainable food and luxury products from distant areas, as well as the transport of passengers and slaves, resulted in the rapid development of maritime transport. With flourishing of maritime trade, there was a need to introduce legal rules which would be used to deal with numerous problems that emerged during its development.

After the conquest of the island of Rhodes, the Romans resorted to the reception of already existing provisions on maritime law, which was of great help in the process of developing legal rules on this subject matter. Thanks to these provisions, as well as the activities of the praetor, who introduced practical solutions in order to resolve many problems encountered in practice and thus contributed to the development of maritime trade, there was an increasing emphasis on the consensus of the contracting parties. For this reason, the contract on the transport of goods by sea was included in a group of consensual contracts. Thus, this contract was referred to as a special form of locatio-conductio contract. As a specific form of locatio-conductio operis faciendi, it was a consensual, double-binding, cargo, bona fides contract, as defined in the era of the Roman Republic, and protected by actio conducti and actio locati. 


\section{REFERENCES}

Bolanča, D; Amižić, P; Pezelj, V. - General average - an ancient institution of maritime law, Ius Romanum, 2/2017, Available at: http://iusromanum.eu; (accessed 1.10 2018)

Boras, M.; Margetić, L. - Rimsko pravo, Zagreb, 1980;

Bujuklić, Ž. - Rimsko privatno pravo, Beograd, 2013;

Casson, L. - Ancient Mariners, London, 1960;

Đorđević, M. - Strukture i posebne vrste locatio-conductio operis faciendi, Strani pravni život, br.3/2014, Beograd, 2014;

Gai Inst. III, 147, prevod: Stanojević, O., Beograd, 2009;

Ignjatović, M. - Actio furti et damni adversus nautas kao oblik osiguranja putnika na brodu, Zbornik radova sa međunarodne naučne konferencije "Suvremeni izazovi pomorske plovidbe", Split, 29. - 30. septembar, 2017;

Ignjatović, M. - Da mihi facto, dabo tibi ius (stvaranje, kreiranje, tumačenje i primena prava u starom Rimu), Zbornik na trudovi, Treta medjunarodna konferencija „Opštestveni promeni vo globalniot svet“, Praven fakultet, Štip, 2016;

Ignjatović, M. - Zaštita ljudskih i manjinskih prava u doba rimske republike, Zbornik radova Pravnog fakulteta Univerziteta u Nišu, tematski broj: "Zaštita ljudskih i manjinskih prava u evropskom pravnom prostoru", Pravni fakultet, Niš, 2002, br. 62;

Maškin, A. - Istorija Starog Rima, Beograd, 1997;

Momsen \& Kruger, Lex Rhodia de iactu, Digesta XIV, 2; Available at: http://www.duhaime.org/lawMuseum/ Law article - 383/Lex-Rhodia-The-Ancient-Ancestor-of-Maritime-Law-800-BC.aspx (Accessed 1.10 2018)

Nikčević-Grdinić, J. - Razvoj i unifikacija pomorskog prava, Godišnjak Pravnog fakulteta u Banjoj Luci, br. 30, 2007;

Pezelj, V. - Patronus navis u dalmatinskom statutarnom pravu, Zbornik radova sa međunarodne naučne konferencije "Suvremeni izazovi pomorske plovidbe", Split, 29. - 30. septembar, 2017;

Rouge', J. - Recherches sur l'organisation du commerce maritime en Mediteranee sous l'Empire romain, Paris, 1966 ;

Šarac, M. - Actio exercitoria, Zastupanje u pravnim poslovima u rimskom pravu, Split, 2008;

Šarac, M. - Magister navis, Zastupanje u pravnim poslovima u rimskom pravu, Split, 2008;

Šarac, M; Miletić, T. - Odgovornost brodara u rimskom pravu, Zbornik radova sa međunarodne naučne konferencije "Suvremeni izazovi pomorske plovidbe", Split, 29. - 30. septembar, 2017;

Simonović, Z. - Pomorsko osiguranje prema vizantijskom Nomos Rhodian nautikos u slučajevima potapanja broda, gusarskog napada ili oluje, Teme, XXXIII, br. 3, Niš, 2009;

Stojčević, D. - Rimsko pravo, I deo (društveno-ekonomski uslovi pod kojima se razvijalo rimsko pravo, statusno, porodično, stvarno, nasledno i krivično pravo), Beograd, 1947.

\section{PREVOZ ROBE MOREM KAO POSEBNA VRSTA LOCATIO-CONDUCTIO OPERIS FACIENDI U RIMSKOM PRAVU}

Prevoz robe morem, kao poseban oblik ugovora locatio-conductio operis faciendi, postaje posebno zanimljiv u društvenim oklonostima u periodu nakon punskih ratova, kada je došlo do geografskog širenja rimske države, a posebno do razvoja pomorske trgovine, koja je nužno zahtevala brzo i efikasno zaključivanje pravnih poslova. Sa procvatom pomorske trgovine, javila se potreba i za postojanjem pravnih instrumenata, uz pomoć koje bi se izlazilo u susret sve zahtevnijem prometu robe. Tako je došlo do nastanka ugovora o prevozu robe morem, kao posebnog oblika ugovora locatio-conductio. Ugovor o prevozu robe morem u rimskom pravu, bio je jedan specifičan oblik ugovora locatio-conductio, tačnije locatio-conductio operis faciendi, pa su shodno tome, sva pravila koja su se primenjivala na ovaj ugovor, primenjivala i na njegov specifičan oblik (podvrstu), na ugovor o pomorskom prevozu robe. Za nastanak i punovažnost ovog ugovora, pored postignute saglasnosti volja ugovornih strana, bilo je neophodno i da budu ispunjeni uslovi u pogledu predmeta ugovora. Predmet ovog ugovora bio je specifičan, pa nije bio sam rad ili radna snaga, već konačni rezultat rada (opus), tj. da se preveze roba sa jednog mesta na drugo, i naknada (merces), koja se za takvu uslugu plaćala.

Ključne reči: pomorska trgovina, prevoz robe morem, locatio-conductio operis faciendi, opus, merces. 